\title{
STRATEGI PENGELOLAAN PARIWISATA HALAL KOTA SURABAYA
}

\author{
Ahyak \\ SMK Miftahul Ulum Karangdurin Karangpenang, Sampang \\ syaifahya91@gmail.com
}

\begin{abstract}
Professional management of management by Coordinating with the tourism office, promoting scientific activities as the cultivation of religious values, and fostering human resources (HR) to all Nadzirs. Management strategies in the traditional tourism sector by offering alternatives such as religious tourism, culinary delights, and traditional markets. 2) Inhibiting factors: Human resource awareness from both tourists and Nadzirs, inadequate facilities related to visitors' quantity. 3) Supporting factors: Islamic environment such as separation of places for male and female tourists, preparation of facilities such as electricity, water, lodging, places for ablution, toilets, and mosques. Suggestion: Conduct training related to the development of halal tourist attractions, provide directions to all tourists both online and offline, expand tourist areas by acquiring surrounding land, rejuvenating and repairing areas, and reforestation.
\end{abstract}

Keywords: Management Strategy, "Halal Tourism", Sunan Ampel.

\begin{abstract}
Abstrak: Tujuan penelitian ini adalah untuk mengetahui pengelolaan, faktor pendukung, dan penghambat dalam strategi pengelolaan Wisata Sunan Ampel Surabaya. Penelitian ini menerapkan metode kualitatif (observasi, dokumentasi, dan wawancara). Hasil penelitian ini antara lain: 1) Profesionalitas pengelolaan manajemen dengan: Berkoordinasi dengan dinas pariwisata, menggalakkan kegiatan ilmiah sebagai penanaman nilai agama, dan pembinaan sumber daya manusia (SDM) kepada semua Nadzir. Strategi pengelolaan di bidang wisata secara tradisional dengan menawarkan alternatif seperti wisata religi, kuliner, dan pasar tradisional. 2) Faktor penghambat: Kesadaran SDM baik dari kalangan wisatawan maupun Nadzir, fasilitas yang kurang memadai berkaitan dengan kuantitas pengunjung. 3) Faktor Pendukung: Lingkungan Islami seperti pemisahan tempat bagi wisatawan laki-laki dan perempuan, penyiapan sarana seperti listrik, air, penginapan, tempat wudhu, toilet, dan masjid. Saran: Mengadakan pelatihan terkait pengembangan tempat wisata halal, memberikan arahan kepada semua wisatawan baik secara daring maupun luring, memperluas kawasan wisata dengan pembebasan tanah sekitar, peremajaan dan perbaikan kawasan, serta penghijauan.
\end{abstract}

Kata Kunci: Strategi Pengelolaan, “Wisata Halal”, Sunan Ampel.

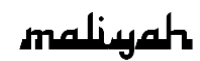

Jurnal Hukum Bisnis Islam

Volume 9 Nomor 2, Desember 2019

p-ISSN: 2088-4869/ e-ISSN: 2597-4351 


\section{Pendahuluan}

Indonesia saat ini diketahui sebagai Negara dengan mayoritas penduduk Muslim terbesar di dunia, data BPS tahun 2010 jumlah penduduk Muslim Indonesia sebesar 207.176.162,1 maka sudah sepatutnya sektor pariwisata melihat hal ini sebagai sebuah ceruk pasar baru yang potensial, dengan menggabungkan konsep pariwisata dan nilai-nilai keIslaman maka halal pariwisata menjadi jawaban atas kondisi tersebut.

Peluang dari pengembangan pariwisata halal yaitu potensi pasar baik wisatawan domestik (penduduk Indonesia 90\% beragama Islam) maupun mancanegara (khusus Timur Tengah dan Malaysia cukup menjanjikan). Potensi yang menjanjikan terhadap pengembangan pariwisata Islami atau pariwisata syariah di Indonesia semakin diperkuat dengan launching pariwisata syari'ah pada tanggal 30 Oktober 2013 pada acara Indonesia Halal Expo (INDEX) di Jakarta Internasional Expo yang didukung oleh Kemenparekraf dan Majelis Ulama Indonesia (MUI).

Menurut Suherman, Jumlah kunjungan wisatawan ke Indonesia beberapa tahun terakhir ini di dominasi oleh wisatawan asal negara-negara ASEAN seperti; Malaysia, Singapura, dan lain-lain. Selain itu juga dari beberapa Negara Eropa, terutama Rusia, kemudian dari Amerika, Australia, dan Negara-negara Timur Tengah seperti Saudi Arabia, Qatar, dan lain-lain. Dari beberapa negara tersebut, potensi kunjungan terbesar pariwisata manca negara ke Indonesia dari luar negara-negara ASEAN ialah dari Negara- negara Timur Tengah terutama Saudi Arabia, Uni Emirat Arab dan beberapa negara di kawasan teluk.

Pariwisata syariah merupakan suatu tren baru dalam dunia pariwisata saat ini. Indonesia telah dikenal luas di dunia

\footnotetext{
${ }^{1}$ Kurniawan Gilang Widagdyo, Analisis Pasar Pariwisata Halal Indonesia, The Journal of Tauhidinomics Vol.1 No.1 (2015): 73-80.
} 
sebagai pariwisata halal terbaik di dunia atas kemenangannya dalam event "The World Halal Travel Summit \& Exhibition 2015". Indonesia berhasil mendapatkan tiga penghargaan sekaligus, meliputi; World Best Family Friendly Hotel, World Best Halal Honeymoon Destination dan World Best Halal Tourism Destination. Hal ini tentunya menjadi sebuah peluang besar yang memudahkan negara Indonesia untuk terus melakukan pengembangan pariwisata syariah dan industri jasa syariah, sehingga Indonesia dapat menanamkan bahwa pariwisata syariah identik dengan Negara Indonesia di dalam mindset pariwisata dunia.

Manusia merupakan makhluk sosial sehingga untuk menyambung kehidupan sehari-hari mereka memerlukan interaksi dengan sesamanya. Di dalam sebuah masyarakat tentunya tidak lepas dari tradisi, karena tradisi kebudayaan akan selalu melekat pada diri masyarakat. Masyarakat pada umumnya memiliki tradisi berpariwisata dan juga memiliki budaya religi dengan cara berpariwisata religi. Sebelum berbicara mengenai pariwisata religi maka pariwisata sendiri memiliki arti yang menarik untuk diketahui. Pariwisata ialah aktivitas bersantai atau aktivitas waktu luang. Perjalanan pariwisata bukanlah hal yang wajib dilakukan, namun pada umumnya dilakukan pada musim libur atau seseorang yang bebas dari pekerjaan yang ia lakukan bisa jadi saat libur atau cuti. Pariwisata dapat diidentikkan dengan berlibur di daerah lain atau memanfaatkan waktu luang dengan melakukan perjalanan pariwisata. ${ }^{2}$

Agama memainkan peran penting dalam pengembangan pariwisata selama berabad-abad dan telah mempengaruhi bagaimana orang memanfaatkan waktu luang. Menjelaskan bahwa peningkatan jumlah wisatawan dengan motivasi agama juga telah menarik perhatian akademisi, pemerintah dan

2 I Gede Pitana and Putu G. Gayatri, Sosiologi Pariwisata (Yogyakarta: ANDI, 2007). 47 
lembaga pariwisata untuk mengembangkan pariwisata. ${ }^{3}$ Studi tersebut menunjukkan bahwa tujuan utama bagi sejumlah besar wisatawan agama terkait dengan kunjungan pada situs dari alkitab, al-Quran atau teks-teks suci lain, atau dengan adanya spiritualisme, seperti mukjizat dan wahyu.

Pengembangan pariwisata halal menjadi alternatif bagi industri pariwisata di Indonesia seiring dengan tren pariwisata halal yang menjadi bagian dari industri ekonomi Islam global. Dinamika pariwisata dunia dalam tiga tahun terakhir dipengaruhi oleh peningkatan jumlah perjalanan antar negara dan pertumbuhan perekonomian terutama di kawasan Asia Pasifik. Total wisatawan dunia pada tahun 2014 mencapai 1.110 juta perjalanan luar negeri atau tumbuh 5\% dibandingkan tahun sebelumnya. Pada tahun 2014 lebih dari 300 juta $(27,1 \%$ dari total wisatawan dunia) melakukan pariwisata ke Asia dan 96,7 juta diantaranya masuk ke Asia Tenggara. Sementara pada tahun 2015 ditengah situasi global yang tidak kondusif, perjalanan wisatawan dunia masih tumbuh $4,5 \%$. Jadi, pariwisata tetap mengalami pertumbuhan signifikan.

Berdasarkan data dari PEW Research, populasi Muslim dunia mencapai angka 1,7 miliar jiwa, dan menurut Thomson Reuters Global Islamic Economy Report 2017-2018, konsumsi Muslim terbesar di dunia pada 6 sektor yaitu; makanan, pariwisata, $\mathrm{p}$

akaian, farmasi, media/rekreasi, dan kosmetik sebesar US \$ 2 triliun atau 11,9\% dari konsumsi masyarakat di dunia dan angka tersebut di atas konsumsi masyarakat Tiongkok di 6 sektor tersebut sebesar US \$1,8 triliun atau 11,3\% dari konsumsi masyarakat di dunia. ${ }^{4}$

3 Ibid. 9

${ }^{4}$ Muhammad Djakfar, H, Pariwisata Halal Perspektif Multidimensi; Peta Jalan Menuju Pengembangan Akademik \& Industri Halal Di Indonesia (Malang: UIN Maliki Press, 2017).4 
Pasar pariwisata halal termasuk Top 5 pasar pariwisata terbesar di dunia. Pengeluaran turis Muslim menurut Thomson Reuters SGIE Report 2017-2018 di tahun 2016 mencapai US\$ 169 miliar dengan tingkat pertumbuhan 6,3\% per tahun jika dibandingkan dengan pengeluaran turis dari Tiongkok di tahun yang sama sebesar US\$ 179 miliar dengan tingkat pertumbuhan $3,5 \%$ per tahun, pasar pariwisata Halal adalah termasuk Top 3 sumber wisatawan dunia. ${ }^{5}$

Pengembangan pariwisata halal menjadi alternatif bagi industri pariwisata di Indonesia seiring dengan tren pariwisata halal yang menjadi bagian dari industri ekonomi Islam global. Dinamika pariwisata dunia dalam tiga tahun terakhir dipengaruhi oleh peningkatan jumlah perjalanan antar negara dan pertumbuhan perekonomian terutama di kawasan Asia Pasifik. Total wisatawan dunia pada tahun 2014 mencapai 1.110 juta perjalanan luar negeri atau tumbuh $5 \%$ dibandingkan tahun sebelumnya. Pada tahun 2014 lebih dari 300 juta $(27,1 \%$ dari total wisatawan dunia) melakukan pariwisata ke Asia dan 96,7 juta diantaranya masuk ke Asia Tenggara. Sementara pada tahun 2015 ditengah situasi global yang tidak kondusif, perjalanan wisatawan dunia masih tumbuh $4,5 \%$. Jadi, pariwisata tetap mengalami pertumbuhan signifikan.

Di Jawa Timur banyak terdapat tempat pariwisata religi yang sangat terkenal, karena dipelopori oleh Wali Songo, termasuk salah satunya pariwisata religi Sunan Ampel. Sunan Ampel sendiri hanyalah sebuah julukan, Sunan adalah gelar kewalian dari kata dalam bahasa Jawa Susuhunan yang artinya dijunjung tinggi. Sedangkan Ampel adalah nama daerah tempat tinggalnya yaitu Ampeldenta atau Ampelgading, sekarang terletak di Kelurahan Ampel, Kecamatan Semampir, Kotamadya Surabaya, Provinsi Jawa Timur, Indonesia. Nama sebenarnya dari Sunan Ampel adalah Raden Rahmat lahir dan wafatnya

5 Ibid.5 
kurang lebih tahun 1401-1481 M.6 Peziarah yang datang ke Makam Sunan Ampel cukup banyak, peziarah yang datang ke sana biasanya dengan tujuan untuk berdo'a, mencari ketenangan batin serta untuk meminta berkah.

Pariwisata Sunan Ampel terus berbenah dalam aspek manajemen guna menjaga kepuasan para peziarah yang datang dan juga meningkatkan mutu pelayanan pada peziarah. Pada hakikatnya manajemen adalah suatu ilmu atau seni mengatur proses pemanfaatan sumber daya manusia dan sumber-sumber lainnya secara efektif dan efesien untuk mencapai suatu tujuan tertentu. Dengan adanya manajemen yang baik dalam pengelolaan pariwisata religi diharapkan bisa membuat para peziarah yang datang bisa merasa nyaman. Manajemen pada pengelolaan pariwisata religi bisa digunakan untuk merencanakan suatu progam untuk menjaga para peziarah yang datang tidak terjerumus kedalam kemusyrikan. Tanpa adanya manajemen, sebuah onyek pariwisata religi akan hanya sekedar menjadi tempat berziarah saja, tanpa mempunyai daya tarik yang lebih.

Masyarakat memiliki budaya religi dengan cara berziarah atau mendatangi tempat-tempat yang dianggap istimewa. Dari adanya fenomena ini budaya religi tersebut dapat dimanfaatkan secara ekonomi oleh masyarakat sekitar. Maksud dari masyarakat sekitar yakni, semua orang yang tidak melakukan pariwisata religi namun para warga sekitar atau masyarakat yang memanfaatkan tempat pariwisata religi untuk mengais rizki atau mendapatkan penghasilan.

Dalam hal ini, penulis mengambil contoh makam Sunan Ampel sebagai salah satu tempat pariwisata halal atau religi yang ramai dikunjungi oleh para peziarah. Pariwisata religi Sunan Ampel yakni sebuah makam wali Allah yang berada di jalan KH Mas Mansyur Kelurahan Ampel, Semampir, Surabaya, Jawa Timur. Makam Sunan Ampel ini sangat ramai dikunjungi oleh para peziarah pada setiap harinya. Lokasi pariwisata religi

${ }^{6}$ Masykur Arif, Sejarah Lengkap Wali Sanga (Yogyakarta: DIPTA, 2013).69

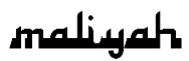


Sunan Ampel sangat strategis tepatnya berada di tengahtengah kota. Dengan adanya berbagai macam tempat pariwisata di Kelurahan yang sama maka sedikit banyak menguntungkan masyarakat yang tinggal di sekitar tempattempat pariwisata itu. Karena tempat pariwisata-pariwisata itu bisa ramai dikunjungi banyak orang serta ada banyak hal yang bisa dilakukan masyarakat sekitar agar bisa memperoleh keuntungan pribadi.

\section{Konsep Strategi}

Kata strategi berasal dari bahasa Yunani "strategia" yang diartikan sebagai "the art of the general" atau seni seorang panglima yang biasanya digunakan dalam peperangan. Strategi berkaitan dengan arah tujuan dan kegiatan jangka panjang suatu organisasi. ${ }^{7}$

Strategi juga sangat terkait dalam menentukan bagaimana suatu organisasi menempatkan dirinya dengan mempertimbangkan keadaan sekeliling terutama terhadap pesaingnya. Strategi merupakan usaha untuk mencapai keunggulan dalam persaingan yang sesuai dengan keinginan untuk dapat bertahan sepanjang waktu, bukan dengan gerakan muslihat, tetapi dengan mengambil wawasan jangka panjang yang luas dan menyeluruh. ${ }^{8}$

Menurut Mudrajad Kuncoro memandang strategi sebagai suatu proses, yang meliputi sejumlah tahapan yang saling berkaitan dan berurutan. Tahapan utama proses manajemen stratejik umumnya mencakup analisis situasi, formulasi strategi, implementasi strategi, dan evaluasi kinerja. Strategi juga bersifat kontekstual, harus sesuai (fit) dengan kompetensi inti dan tantangan yang dihadapi. Maka dapat disimpulkan strategi adalah pilihan tentang tindakan yang

\footnotetext{
7 Sularno Tjiptowardoyo, Strategi Manajemen (Jakarta: PT. Elex Media Komputindo, 1995).3

${ }^{8}$ Ibid. 4
} 
dilakukan oleh organisasi untuk mencapai tujuannya dan untuk mencapai keunggulan kompetitif. ${ }^{9}$

Prinsip-prinsip untuk mensukseskan strategi menurut Hatten, yaitu: ${ }^{10}$

1. Strategi haruslah konsisten dengan lingkungannya

2. Setiap organisasi tidak hanya membuat satu strategi

3. Strategi yang efektif hendaknya memfokuskan dan menyatukan semua sumber daya dan tak menceraiberaikan satu dengan yang lainnya

4. Strategi hendaknya memusatkan perhatian pada apa yang merupakan kekuatannya dan tidak pada titik-titik yang justru adalah kelemahannya

5. Strategi hendaknya memperhitungkan resikoyang tidak terlalu bisa

6. Tanda-tanda dari suksesnya strategi ditampakkan dengan adanya dukungan dari pihak-pihak terkait.

Strategi sendiri memiliki manfaat yang sangat besar, Adapun manfaat dari strategi adalah sebagai berikut:

1. Efisiensi dan aktivitas kerja

2. Meningkatkan kreativitas kerja

3. Tanggung jawab lebih meningkat kepada perusahaan atau diri sendiri

4. Rencana perusahaan lebih jelas

5. Pengendali dalam mempergunakan sumber daya yang dimiliki secara terintegrasi dalam pelaksanaan fungsi-fungsi manajemen agar berlangsung sebagai proses yang efektif dan efisien. ${ }^{11}$

\section{Konsep Pengelolaan Pariwisata Halal}

\footnotetext{
${ }_{9}^{9}$ Mudrajad Kuncoro, Strategi Bagaimana Meraih Keuggulan Kompetitif (Jakarta: Erlangga, 2006).9

10 J Salusu, Pengambilan Keputusan Strategi Untuk Organisasi Publik Dan

Organisasi Non Profit (Jakarta: PT. Grasindo, 2003).108

11 Syukai, "Manfaat Dan Proses Manajemen Strategi,"

http://syukai.wordpress.com/2009/06/15/manfaat-dan-proses-

manajemenstrategi/. (24 Juni 2018)
} 
Dalam Kamus Besar Bahasa Indonesia mendefinisikan pengelolaan berarti proses, cara, perbuatan pengelola, proses melakukan kegiatan tertentu dengan menggerakkan tenaga orang lain, proses yang membantu merumuskan kebijaksanaan dan tujuan organisasi, proses yang memberikan pengawasan pada semua hal yang terlibat dalam pelaksanaan kebijakan dan pencapaian tujuan. ${ }^{12}$

Pengelolaan merupakan pengertian yang lebih sempit dari kepemimpinan, pengelolaan merupakan jenis kepemimpinan yang khusus, yang paling penting dalam pengelolaan adalah tercapainya tujuan organisasional lembaga. Kunci perbedaan antara kepemimpinan dan pengelolaan adalah kata organisasi (organization). Dengan latar belakang perbedaan itu, pengelolaan didefinisikan sebagai bekerja dengan lewat orang-orang secara pribadi dan kelompok untuk mencapai tujuan organisasional lembaga. Seorang pemimpin dapat mencapai tujuannya sendiri atau membantu orang lain mencapai tujuan. Pengelolaan terutama harus ditujukan kepada pencapaian tujuan kelompok atau lembaga. ${ }^{13}$

Menurut Handoko, manajemen dapat didefinisikan sebagai bekerja dengan orang-orang untuk menentukan, menginterpretasikan dan mencapai tujuan-tujuan organisasi dengan pelaksanaan fungsi-fungsi perencanaan (planning), pengorganisasian (organizing), penyusunan personalia atau kepegawaian (staffing), pengarahan dan kepemimpinan (leading), dan pengawasan (controlling). ${ }^{14}$

Menurut G.R. Terry Manajemen adalah sebuah proses yang khas, yang terdiri dari tindakan-tindakan perencanaan, pengorganisasian, penggerakan dan pengendalian yang dilakukan untuk mencapai sasaran-sasaran yang telah

\footnotetext{
12 Alwi Hasan Dkk, Kamus Besar Bahasa Indonesia (Jakarta: Departemen Pendidikan Nasional Balai Pustaka, 2005).534

13 Charles J, Keating, Kepemimpinan Teori Dan Pengembangannya

(Yogyakarta: Kanisius, 1995).75

14 T. Hani Handoko, Manajemen (Yogyakarta, 2004).8
} 
ditetapkan melalui pemanfaatan sumber daya manusia dan sumber-sumber lainnya. ${ }^{15}$

Dari beberapa definisi di atas dapat disimpulkan bahwa, pengelolaan sama dengan manajemen yaitu upaya untuk mencapai tujuan melalui orang lain. Sebagaimana penjelasan di atas manajemen atau pengelolaan untuk mencapai tujuan dengan menjalankan manajemen secara garis besar yang berfungsi sebagai; perencanaan (planning), pengorganisasian (organizing), pelaksanaan (actuating), dan pengawasan (controlling).

Pengembangan pariwisata pada hakekatnya adalah suatu proses dalam rangka memperbaiki dan meningkatkan sesuatu yang telah ada. Pengembangan pariwisata dapat berupa kegiatan pembangunan, pemeliharaan dan pelestarian tanaman, sarana dan prasarana maupun fasilitas lainnya. Pengembangan pariwisata juga merupakan kegiatan pengembangan masyarakat dan wilayah yang didasarkan pada: ${ }^{16}$ Memajukan tingkat hidup masyarakat sekaligus melestarikan identitas lokal; Meningkatkan tingkat pendapatan secara ekonomis serta pendistribusikan merata kepada masyarakat; Berorientasi kepada pengembangan pariwisata berskala kecil dan menengah dengan daya serap tenaga kerja besar dan berorientasi kepada teknologi kooperatif; dan memanfaatkan pariwisata seoptimal mungkin sebagai penyumbang tradisi negara. Pengembangan wisata hanya dapat dikembangkan dengan menggunakan suatu strategi khusus. Strategi yang dapat digunakan adalah menggunakan metode analisis SWOT. SWOT merupakan metode yang sangat lazim dan banyak digunakan dalam segala segi pengembangan bisnis termasuk pariwisata, strategi ini dilakukan dengan pengevaluasian terhadap kekuatan (Strengths), kelemahan (weakness), peluang (opportubities), dan ancaman (threats)

\footnotetext{
15 Melayu S. P. Hasibuan, Organisasi Dan Motivasi (Jakarta: PT. Bumi Aksara, 2001). 3

${ }^{16}$ Chafid Fandeli, Dasar-Dasar Manajemen Kepariwisataan, n.d. 24
} 
dalam suatu proyek. SWOT merupakan sebuah alat analisis yang efektif dan efesien sebagai alat yang cepat dalam menemukan kemungkinan yang berkaitan dengan pengembangan awal progam-progam inovasi baru dalam kepariwisataan. Penggunaan analisis SWOT dalam skenario pengembangan pariwisata adalah sebagai berikut: ${ }^{17}$

Kekuatan (strengths) adalah mengetahui potensi wisata suatu wilayah, maka akan dapat bersaing dalam pasar dan mampu untuk pengembangan selanjutnya. Hal ini dapat diggunakan untuk meraih peluang; Kelemahan (weakness) adalah segala sesuatu yang dapat merugikan sektor pariwisata. Pada umumnya kelamahan-kelemahan yang dapat diidentifikasi adalah kurangnya promosi, pelayanan yang tidak maksimal, kurang profesional dalam pengadaan pariwisata di lapangan, dan sulitnya lokasi dijangkau; Kesempatan (opportunities) adalah semua kesempatan yang ada sebagai akibat kebijakan pemerintah, peraturan yang berlaku atau kondisi perekonomian; Ancaman (threath) adalah berupa halhal yang dapat mendatangkan kerugian bagi pariwisata, seperti peraturan yang tidak memudahkan dalam berusaha, rusaknya lingkungan dan lainya.

Islam memberikan kesempatan kepada umatnya untuk berpariwisata religi agar dari sana tumbuh kesadaran akan kesementaraan hidup di dunia. Dengan berziarah (Pariwisata religi) diharapkan tumbuh introspeksi diri. Adapun manfaat dari pariwisata religi, yaitu:

\section{Mengingat Kematian}

Sebagai manusia kita akan ingat mati, dari kesadaran itu diharapkan mendapatkan dorongan untuk mempersiapkan bekal bagi kehidupan setelah mati, dan akan menambah keimanan sehari-hari seperti shalatnya menjadi rajin, sedekahnya bertambah banyak, suka menolong fakir miskin, dan peduli kepada anak yatim.

17 A Yoeti, Oka, Pemasaran Pariwisata (Bandung: Angkasa, 1996).135 


\section{Menambah Amal Shaleh}

Sebagai manusia dapat mengambil ketaladan dari Rasulullah, para sahabat, alim ulama, para wali Allah, dan orang-orang shaleh lainnya, sudah tentu banyak sifat, sikap, dan tindakan yang ditiru, dari kekhusyukan shalatnya, sikap adilnya, suka mengaji, suka menulis, suka menolong sesama, dan hal baik lainnya dapat ditiru manusia untuk menambah amal shaleh. ${ }^{18}$

Tujuan pariwisata religi mempunyai makna yang dapat dijadikan pedoman untuk menyampaikan syiar islam di seluruh dunia, dijadikan sebagai pelajaran, untuk mengingat ke-Esaan Allah. Mengajak dan menuntun manusia supaya tidak tersesat kepada syirik atau mengarah kepada kekufuran. ${ }^{19}$

Selain tujuan dan manfaat pariwisata religi juga mempunyai fungsi antara lain:

1. Untuk aktivitas luar dan didalam ruangan perorangan atau kolektif, untuk memberikan kesegaran, semangat hidup baik jasmani maupun rohani.

2. Sebagai tempat ibadah, sholat, dzikir, dan berdoa.

3. Sebagai salah satu aktivitas keagamaan.

4. Sebagai salah satu tujuan pariwisata-pariwisata umat Islam.

5. Sebagai aktivitas kemasyarakatan.

6. Untuk melakukan ketenangan lahir dan batin.

7. Sebagai peningkatan kualitas anusia dan pengajarannya (ibrah).

Pariwisata religi dilakukan dalam rangka mengambil ibrah atau pelajaran dan ciptaan Allah atau sejarah peradaban manusia untuk membuka hati sehingga menumbuhkan kesadaran bahwa hidup di dunia ini tidak kekal. Pariwisata pada hakikatnya adalah perjalanan untuk menyaksikan tandatanda kekuasaan Allah, implementasinya dalam pariwisata kaitannya dengan proses dakwah dengan menanamkan

18 Munawirul Abdul Fatah, Tuntunan Praktis Ziarah Kubur Makam Walisongo Hingga Makam Rasul (Yogyakarta: Pustaka Pesantren, 2010).34

${ }^{19}$ Arifin S, N and Ruslan, Ziarah Wali Spritual Spanjang Masa, n.d. 10 
kepercayaan akan adanya tanda-tanda kebesaran Allah sebagai bukti ditunjukkan berupa ayat-ayat dalam al-Qur'an.

Sebagaimana telah dijelaskan di atas, bahwa pengelolaan memiliki definisi yang sama dengan manajemen. Selanjutnya dalam pengelolaan atau manajemen memiliki fungsi sebagai berikut: ${ }^{20}$

\section{Perencanaan (planning)}

Menurut G.R. Terry, Planning atau perencanaan adalah tindakan memilih dan menghubungkan fakta serta membuat asumsi atau prediksi mengenai masalah yang akan datang dan merumuskan usulan yang dianggap perlu untuk mencapai hasil yang diinginkan. ${ }^{21}$ Menurut Fayol, Planning yaitu satu pandangan ke depan di mana para manajer memikirkan sumber daya apa saja yang dimiliki. ${ }^{22}$

Adapun dalam perencanaan, manajer memutuskan "apa yang harus dilakukan, kapan melakukannya, bagaimana melakukannya, dan siapa yang melakukannya". Dengan arti lain, perencanaan merupakan pemilihan sekumpulan kegiatan dan pemutusan selanjutnya apa yang harus dilakukan, kapan, bagaimana dan oleh siapa. ${ }^{23}$

Sedangkan dalam fungsi perencanaan yang dapat dilakukan oleh perusahaan atau organisasi yaitu:

a. Menetapkan tujuan dan target bisnis

b. Merumuskan strategi untuk mencapai tujuan dan target bisnis tersebut

c. Menentukan sumber daya yang diperlukan

d. Menetapkan standar/indikator keberhasilan dalam pencapaian tujuan dan target bisnis.

2. Pengorgansasian (organizing)

\footnotetext{
20 Ibid.3-4

21 Iwan Purwanto, Manajemen Strategi (Bandung: Yarma Widya, 2006).45

22 Azhar Arsyad, Pokok-Pokok Manajemen (Yogyakarta: Pustaka Pelajar, 2002).14

${ }^{23}$ Handoko, Manajemen.79
} 
Langkah selanjutnya setelah perencanaan, maka pimpinan atau manajer perlu merancang dan mengembangkannya dengan membentuk organisasi yang akan menjalankan segala keputusan yang telah direncanakan agar dapat tercapai sesuai dengan apa yang diinginkan.

Menurut Fayol Organizing merupakan kegiatan yang mengarah ke "structure activities". Oleh karenanya, diperlukan pemikiran siapa yang melakukan apa, kapan dilakukan, dan bagaimana pekerjaan dilakukan. ${ }^{24}$

G. R. Terry berpendapat bahwa pengorganisasian adalah: "Tindakan mengusahakan hubungan-hubungan kelakuan yang efektif antara orang-orang, sehingga mereka dapat bekerja sama secara efesien dan dengan demikian memperoleh kepuasan pribadi dalam hal melaksanakan tugas-tugas tertentu dalam kondisi lingkungan tertentu guna mencapai tujuan atau sasaran tertentu. ${ }^{25}$ Pengorganisasian (organizing) adalah: 26

a. Penentuan sumber daya dan kegiatan-kegiatan yang dibutuhkan untuk mencapai tujuan organisasi

b. Perancangan dan pengembangan suatu organisasi kelompok kerja yang akan dapat membawa hal-hal tersebut kearah tujuan

c. Penugasan tanggung jawab tertentu dan kemudian

d. Pendelegasian wewenang yang diperlukan kepada individu-individu untuk melaksanakan tugas-tugasnya. Fungsi ini menciptakan struktur formal dimana pekerjaan ditetapkan, dibagi dan dikoordinasikan.

3. Penggerakan (actuating)

Penggerakan dalam bahasa arab "Tansiq": yaitu suatu usaha untuk mengharmoniskan hubungan dalam rangkaian struktur yang ada. Pada hakikatnya yang dikoordinir itu

\footnotetext{
${ }^{24}$ Arsyad, Pokok-Pokok Manajemen.15

25 Hasibuan, Organisasi Dan Motivasi.23

${ }^{26}$ Handoko, Manajemen. 24
} 
adalah manusianya. ${ }^{27}$ Setelah kegiatan-kegiatan dalam rangka pencapaian tujuan itu dibagi-bagikan, maka tindakan berikutnya dari pimpinan adalah menggerakkan mereka untuk segera melaksanakan kegiatan-kegiatan itu, sehingga apa yang menjadi tujuan benar-benar tercapai. ${ }^{28}$

Penggerakan merupakan cara membuat anggota organisasi agar mau bekerja sama dan bekerja secara ikhlas serta semangat untuk mencapai tujuan sesuai dengan perencanaan dan usaha-usaha pengorganisasian. ${ }^{29}$ Fungsi penggerakan yang dilakukan oleh perusahaan atau organisasi yaitu: ${ }^{30}$

a. Mengimplementasikan proses kepemimpinan, pembimbingan, dan pemberian motivasi kepada tenaga kerja agar dapat bekerja secara efektif dan efisien dalam pencapaian tujuan

b. Memberikan tugas dan penjelasan rutin mengenai pekerjaan

c. Menjelaskan kebijakan yang ditetapkan.

\section{Pengawasan (controlling)}

Fungsi terakhir dari pengelolaan atau manajemen sebagai fungsi adalah pengawasan (controlling). Adapun pengawasan merupakan fungsi dari pimpinan yang berhubungan dengan upaya untuk menyelamatkan roda kegiatan organisasi atau perusahaan ke arah cita-cita yang telah direncanakan. ${ }^{31}$

Tujuan utama dari pengawasan adalah mengusahakan agar yang direncanakan dapat menjadi kenyataan. Oleh karenanya, agar sistem pengawasan itu benar-benar efektif

\footnotetext{
${ }^{27}$ Arsyad, Pokok-Pokok Manajemen.15

${ }^{28}$ Abdullah Rosyad Shaleh, Manajemen Dakwah Islam (Jakarta: PT. Bulan

Bintang, 1986).101

${ }^{29}$ Purwanto, Manajemen Strategi.58

30 Ibid.

31 M Manulang, Dasar-Dasar Managemen (Jakarta: Ghalia Indonesia, 1982).171
} 
artinya dapat merealisasi tujuannya, maka suatu sistem pengawasan setidak-tidaknya harus dapat dengan segera melaporkan adanya penyimpangan-penyimpangan dari rencana. ${ }^{32}$

Menurut G.R. Terry, pengawasan dapat dirumuskan sebagai proses penentuan apa yang harus dicapai sesuai standar, apa yang sedang dilakukan yaitu pelaksanaan, menilai pelaksanaan dan bila perlu melakukan perbaikan-perbaikan, sehingga pelaksanaan sesuai dengan rencana atau selaras dengan standar. ${ }^{33}$ Sedangkan kegiatan dalam fungsi penggerakan yang dilakukan oleh perusahaan atau organisasi yaitu: ${ }^{34}$

a. Mengevaluasi keberhasilan dalam pencapaian tujuan dan target bisnis sesuai dengan indikator yang telah ditetapkan

b. Mengambil langkah klarifikasi dan koreksi atas penyimpangan yang mungkin ditemukan

c. Melakukan berbagai alternative solusi atas berbagai masalah yang terkait dengan pencapaian tujuan dan target bisnis.

Pariwisata Halal dimaknai sebagai kegiatan pariwisata ke tempat yang memiliki makna khusus, biasanya berupa tempat yang memiliki makna yang baik menurut pandangan agama Islam.

1. Masjid sebagai tempat pusat keagamaan dimana masjid digunakan untuk beribadah sholat, I'tikaf, adzan dan iqomah.

2. Makam dalam tradisi Jawa, tempat yang mengandung kesakralan makam dalam bahasa Jawa merupakan penyebutan yang lebih tinggi (hormat) pesarean, sebuah kata benda yang berasal dan sare, (tidur). Dalam pandangan tradisional, makam merupakan tempat peristirahatan. ${ }^{35}$

\footnotetext{
32 Ibid.174

33 Purwanto, Manajemen Strategi.67

34 J Smith, Prinsip-Prinsip Manajemen (Jakarta: PT. Bumi Aksara, 1993).18

${ }^{35}$ Agus Suryono, Paket Wisata Ziarah Umat Islam (Semarang: Kerjasama

Dinas Pariwisata Jawa Tengah dan Stiepari Semarang, 2004).7
} 
3. Candi sebagai unsur pada jaman purba yang kemudian kedudukannya digantikan oleh makam.

\section{Sejarah Pengelolaan Wisata Sunan Ampel Surabaya}

Lokasi Wisata Sunan Ampel terletak di jalan Ampel Suci nomer 45 Kelurahan Ampel, Kecamatan Semampir, Kotamadya Surabaya, Provinsi Jawa Timur, Indonesia.

Untuk menuju lokasi makam dan masjid Sunan Ampel bisa melalui beberapa jalan. Bisa lewat jalan Nyamplungan masuk ke gang-gang kecil seperti Gang Ampel Kembang, Gang Ampel Gading dan sebagainya. Bisa juga lewat jalan Sasak masuk ke Gang Ampel Suci, ini yang melewati pasar tradisional ala timur tengah. Atau jika naik kendaraan roda empat dan ingin diparkir langsung di pelataran parkiran Masjid Sunan Ampel bisa lewat jalan K.H. Mas Mansyur masuk ke jalan Petukangan Utara.

Peninggalan-peninggalan sunan ampel yang lestari sampai sekarang seperti Masjid, Gapura, Sumur, Makam Sunan Ampel, Makam Mbah Bolong, Makam Mbah Shonhaji, Makam Nyi Ageng Manila dapat di saksikan secara langsung jika berkunjung ke sana.

Pengelolaan wisata religi sunan ampel di tangani oleh suatu yayasan bernama, Yayasan Masjid Agung Sunan Ampel. Sejarahnya dimulai sejak Sunan Ampel wafat tahun 1481. Sepeninggal Sunan Ampel, pusat pendidikan dan dakwah di Ampeldenta mulai meredup. Saat itu kerajaan Islam pertama di jawa telah berdiri di Demak Bintoro. Sebelum Sunan Ampel meninggal pusat dakwah dewan Wali Sanga telah berpindah ke Demak. ${ }^{36}$ Apalagi setelah keruntuhan kerajaan Majapahit, Demak menjadi pusat pemerintahan terbesar di pulau jawa. Semenjak saat itu tidak terdengar kabar bagaimana keadaan pesantren Ampeldenta selanjutnya.

${ }^{36}$ Ibid. 131 
Kurang lebih 500 tahun kemudian, tepatnya tahun 1972, dibentuk suatu lembaga berbentuk Yayasan yang menjaga, merawat, dan mengelola makam dan masjid peninggalan Sunan Ampel tersebut. Lembaga yang bernama Yayasan Masjid Agung Sunan Ampel tersebut pertama-tama diketuai oleh KH. Mas Muhammad Yusuf. Banyak keterangan yang menyebutkan $\mathrm{KH}$. Mas Muhammad Yusuf masih memiliki garis keturunan dari Sunan Ampel, sebagaimana keterangan putranya KH. Zeid Muhammad Yusuf sebagaimana berikut:

"Sebenarnya dipegang oleh kepengurusan takmir, memang oleh pihak keluarga. Ya katanya saya masih ada keturunan gitu. Namun kami bukan, oh masjid ini dikuasai keluarga bukan gitu.." 37 KH. Zeid Muhammad Yusuf juga menerangkan sebenarnya cucu-cucu Sunan Ampel tetap melanjutkan mengelola pesantren yang didirikan kakeknya itu setelah Sunan Ampel meninggal.

Namun pada masa pendudukan VOC di Surabaya banyak tempat-tempat milik Sunan Ampel yang ditukar guling dipindahkan ke tempat lain untuk kemudian tempat itu digunakan kepentingan VOC. Seperti misalnya pasar ikan Pabean ditempat itu dulu ada pondok pesantren milik cucu ke6 dari Sunan Ampel yakni Kyai Abdullah Mansyur. Karena tempatnya yang strategis sebagai jalur perdagangan dan transportasi air laut dan sungai akhirnya diambil alih oleh pemerintah dan VOC. ${ }^{38}$ Sejak tahun 1970-an awal tanah wakaf, makam dan masjid yang didirikan.

Sunan Ampel dikelola oleh sebuah lembaga pengelola wakaf atau yang biasa disebut Nadzir. Nadzir pertama Masjid Agung Sunan Ampel adalah K.H. Mas Muhammad bin Yusuf. Beliau adalah seorang Kyai kharismatik, seorang Muqaddam

37 Zeid Muhammad Yusuf (Takmir MASA Bidang Peribadatan), Wawancara, Surabaya, 30 Mei 2018.

38 Zeid Muhammad Yusuf (Takmir MASA Bidang Peribadatan), Wawancara, Surabaya, 30 Mei 2018. 
atau Mursyid dari Thariqat Tijaniyah di Jawa Timur. ${ }^{39}$ yang juga memiliki nasab keturunan langsung dari Raden Rahmatullah atau Sunan Ampel. ${ }^{40}$

Nadzir kedua dipegang oleh K.H. Nawawi Muhammad pendiri Lembaga Pengajaran dan Kursus Bahasa Arab Masjid Agung Sunan Ampel (LPBA MASA). ${ }^{13}$ Beliau menjabat sebagai Nadzir sampai beliau meninggal tahun 1998. Sepeninggal Nadzir ke-2 sampai tahun 2017 ini belum ada Nadzir ke-3 sebagai pelanjutnya, namun lembaga ke-Nadzir-an yang telah berbentuk Yayasan, yakni Yayasan Masjid Agung Sunan Ampel tetap memiliki kepengurusan yang bisa dianggap sebagai "Pelanjut Nadzir".

Pelanjut Nadzir atau Pengurus Yayasan Masjid Agung Sunan Ampel yang masih aktif sampai tahun 2017 ini, sejak tahun 1998 diketuai oleh K.H. Ubaidillah bin Muhammad bin Yusuf. Beliau adalah anak dari Nadzir ke-1 Pengelola Wakaf Tanah, Makam dan Masjid Agung Sunan Ampel. Sedangkan Ketua Takmir Masjid Agung Sunan Ampel adalah K.H. Mohammad Azmi Nawawi. Beliau adalah anak dari Nadzir ke2 K.H. Nawawi Muhammad. Struktur kepengurusan yang lain seperti ketua bidang peribadatan dan sejarah diketuai oleh K.H. Zeid Muhammad Yusuf, adik K.H. Ubaidillah, anak dari Nadzir ke-1 K.H. Mas Muhammad Yusuf. Sedangkan bidang lain seperti Lembaga Pengajaran dan Kursus Bahasa Arab Masjid Agung Sunan Ampel (LPBA MASA) dikepalai oleh Gus Ahmad Hifni Nawawi anak dari Nadzir ke-2 wakaf Sunan Ampel K.H. Nawawi Muhammad.

\section{Strategi Pengelolaan Wisata Sunan Ampel}

\footnotetext{
${ }^{39}$ Admin, Buku Tijaniyah Indonesia, n.d., http// www.cheikh-skiredj.com. 190

40 Zeid Muhammad Yusuf (Takmir MASA Bidang Peribadatan), Wawancara, Surabaya, 30 Mei 2018.
} 
Pengelola atau pengurus yang bertindak sebagai Nadzir dalam Strategi pengelolaan dikelola secara profesional maupun tradisional di wisata Sunan Ampel Surabaya sebagai berikut:

1. Pengelolaan Manajemen Secara Profesional

a. Berkoordinasi dengan Dinas Pariwisata.Dalam hal ini pihak Nadzir Wisata Sunan Ampel dituntut untuk melaporkan kinerja pengurus dalam menjalankan semua programnya, ini disebabkan karena pihak Dinas Pariwisata Kota Surabaya sebagai Instansi yang memantau langsung kinerja para Nadzir Wisata Sunan Ampel dan melakukan pengawasan dalam pengembangan pariwisata selaku penanggungjawab pengelolaan tempattempat wisata di wilayah kota Surabaya. Pihak Dinas Pariwisata Surabaya mempunyai kewajiban untuk selalu menguntrol dan mengevaluasi dalam perkembangannya sebagai bentuk tanggungjawabnya dalam mengelola cagar budaya yang diakui oleh pemerintah kota Surabaya.

b. Mengadakan Kegiatan Ilmiah. Kegiatan keagamaan yang dilaksanakan oleh pengurus (nadzir) Sunan Ampel merupakan salah satu potret dan cara dalam menanamkan nilai-nilai kagamaan sehingga image akan halal wisata akan tetap melekat terhadap tempat wisata utamanya wisata Sunan Ampel Surabaya. Kegiatan ini dilaksanakan secara rutin dalam satu tahun satu kali selama tiga hari dengan pembagian waktu yang berbidabeda yaitu hari pertama untuk wanita hari kedua untuk laki-laki dan hari ketiga diisi dengan kegiatan bakti sosial, kegiatan ini sebagai gambaran akan wisata karena setiap kegiatan yang dilakukan bernuansa islami, ini dapat dibuktikan dengan seringnya mendatangkan dai-dai kondang untuk memberi siraman rohani keagamaan pada anggota yang hadir pada kegiatan tersebut.

c. Pembinaan sumber daya manusia. Pembinaan dalam pengelolaan wisata terhadap para pelaksana tugas (sumber daya manusia) merupakan salah satu stategi yang digunakan dalam pengelolaan wisata Sunan Ampel Surabaya, hal ini merupakan satu langkah lebih maju 
karena semakin berkembangnya pengelolaan wisatawisata dari berbagai sektor. Adapun pembinaan yang dilakukan adalah pelatihan yg diberikan langsung oleh Dinas Pariwisata dan evaluasi kenerja dari berbagai sektor sesuai dengan jobnya masing-masing. Pembinaan dengan pendekatan secara persuasive selalu dilakukan secara berkala guna untuk meningkatkan kualitas pelayanan pada peziaroh, ini terbilang sangat efektif dan efesien karena bertatap muka langsung dengan petugas yang diberi pembinaan.

Berdasarkan hasil analisis peneliti, bahwa strategi pengelolaan di Wisata Sunan Ampel Surabaya dilakukan secara profesional, hal ini selaras dengan teori yang jelaskan oleh Handoko, bahwa salah satu manajemen pengelolaan adalah adanya perencanaan (planning), pengorganisasian (organizing), penyusunan personalia atau kepegawaian (staffing), pengarahan dan kepemimpinan (leading), dan pengawasan (controlling), sehingga bentuk kerjasama yang dilakukan oleh pihak pengurus (nadzir) Sunan Ampel dengan Dinas Pariwisata sangat sesuai dan tepat karena pihak Dinas Pariwisata bukan hanya sebagai pengarah dan kepemimpinan (leading), akan tetapi juga sebagai pengawas (agen of control).

2. Pengelolaan Wisata Secara Tradisional

Pada kawasan Wisata Ampel Surabaya menawarkan banyak alternatif wisata, seperti wisata religi, wisata kuliner, dan wisata pasar tradisional, yang mana dikelola secara tradisional dan mengalir secara alamiah. Pihak Nadzir belum bisa mengembangkannya secara produktif modern dikarenkan aset tanah wisata bukan milik Wisata Sunan Ampel Surabaya, melainkan milik perorangan, disamping sulitnya investor yang bersedia membiayai disebabkan lokasi yang kurang strategis, selain itu pula sulitnya birokrasi dengan para pedagang yang sudah kadung nyaman ada di lokasi lapaknya masing-masing. Beberapa wisata alternatif tersebut sering dikunjungi oleh para wisatawan 
maupun non wisatwan sebagai obyek bisnis syariah di wilayah lingkungan Wisata Sunan Ampel.

\section{Analisis Faktor Penghambat dan Pendukung Pengelolaan Wisata Sunan Ampel}

Faktor penghambat pengelolaan wisata Sunan Ampel, sebagaimana berikut:

1. Kesadaran SDM. Dalam hal ini, para wisatawan yang berkunjung masih banyak yang tidak mematuhi prosedur pengunjung yang telah ditetapkan oleh Nadzir Wisata Sunan Ampel. Hal ini disebabkan karena kurangnya kesadaran wisatawan untuk kerjasama dengan pihak pengelola sehingga banyak peraturan yang sering dilanggar seperti banyak perempuan yang masih ikut pada tempat laki-laki kerena alasan satu rombongan dan bersama suami. Nadzir selaku pengelola Wisata Sunan Ampel selama ini masih terpaku pada pengelolaan tradisional, dimana sistem pengelolaan ini dihasilkan berdasarkan sistem turuntemurun dari Nadzir-nadzir sebelumnya, sehingga masih banyak objek wisata lain yang pengelolaannya kurang maksimal dan berkembang, seperti kurangnya promosi baik di media cetak maupun media elektronik, dan ini berdampak pula pada pendapatan di Wisata Sunan Ampel sendiri.

2. Fasilitas Kurang Memadai. Terbatasnya tempat wisatawan yang tersedia merupakan salah satu faktor penghambat dalam pengelolaan halal wisata atau wisata Sunan Ampel Surabaya terutama di hari-hari besar atau hari libur karena pada hari tersebut banyak pengunjung yang berdatangan untuk berziyaroh sehingga tempat yang tersedia tidak mencukupi pada wisatawan yang datang, dengan demikian banyak wisatawan perempuan menempati tempat wisatawan laki-laki namun tidak sebaliknya.

Faktor Pendukung Pengelolaan Wisata Sunan Ampel Surabaya sebagaimana berikut:

1. Lingkungan Islami bagi Wisatawan. Lingkungan yang islami di Wisata Sunan Ampel terwujud dalam pemisahan 
penyediaan tempat bagi para wisatawan laki-laki dan perempuan. Hal ini harus dilakukan karena Wisata Sunan Ampel adalah salah satu destinasi pariwisata halal yang sesuai dengan tuntunan syariat Islam, sebagai upaya untuk menghindarkan bercampurnya wisatawan laki-laki dan permpuan yang bukan mahromnya.

2. Penyiapan Sarana Prasarana bagi Wisatawan. Pada objek wisata Sunan Ampel sangat memperhatikan fasilitas dan sarana prasananya meskipun untuk saat ini kurang memadai, mulai dari listrik, air, telekomunikasi, penginapan, tempat wudhu', tempat mandi, masjid dan lain sebagainya. Selain fasilitas tempat, papan nama dan rambu-rambu bertuliskan tiga bahasa, yakni bahasa indonesia, arab, dan inggris juga tersedia sebagai petunjuk bagi para wisatawan Wisata Sunan Ampel yang datang dari berbagai manca negara.

\section{Penutup}

Berdasarkan pembahasan pada bab-bab sebelumnya, maka Strategi pengelolaan dibidang manajemen Wisata Sunan Ampel Surabaya, dikelola secara profesional dengan: Pertama, Berkoordinasi dengan Dinas Pariwisata yang mana pihak Nadzir Wisata Sunan Ampel melaporkan kinerja pengurus dalam menjalankan semua programnya. Kedua, Mengadakan Kegiatan Ilmiah sebagai salah satu potret dalam menanamkan nilai-nilai kagamaan. Ketiga, Pembinaan sumber daya manusia dengan mengadakan pelatihan kepada semua Nadzir untuk meningkatkan kualitas pelayanan terhadap para wisatawan. Strategi pengelolaan dibidang Wisata dikelola secara tradisional, dengan menawarkan banyak alternatif wisata, seperti wisata religi, wisata kuliner, dan wisata pasar tradisional, yang mana dikelola secara tradisional dan mengalir secara alamiah.

Adapun faktor penghambat pengelolaan wisata Sunan Ampel, seperti: Pertama, Kesadaran SDM baik dari kalangan Wisatawan maupun Nadzir. Kedua, Fasilitas Kurang Memadai terutama di hari-hari besar atau hari libur karena banyaknya 
pengunjung yang berdatangan. sedangkan faktor Pendukung Pengelolaan Wisata Sunan Ampel Surabaya seperti: Pertama, Lingkungan Islami bagi Wisatawan yang terwujud dalam pemisahan penyediaan tempat bagi para wisatawan laki-laki dan perempuan. Kedua, Penyiapan Sarana Prasarana bagi Wisatawan mulai dari listrik, air, telekomunikasi, penginapan, tempat wudhu', tempat mandi, masjid dan lain sebagainya. Selain fasilitas tempat, papan nama dan rambu-rambu bertuliskan tiga bahasa, yakni bahasa indonesia, arab, dan inggris juga tersedia sebagai petunjuk bagi para wisatawan Wisata Sunan Ampel yang datang dari berbagai manca negara.

\section{Daftar Pustaka}

Abdul Fatah, Munawirul. Tuntunan Praktis Ziarah Kubur Makam Walisongo Hingga Makam Rasul. Yogyakarta: Pustaka Pesantren, 2010.

Admin. Buku Tijaniyah Indonesia, n.d. http// www.cheikhskiredj.com.

Arif, Masykur. Sejarah Lengkap Wali Sanga. Yogyakarta: DIPTA, 2013.

Arsyad, Azhar. Pokok-Pokok Manajemen. Yogyakarta: Pustaka Pelajar, 2002.

Djakfar, H, Muhammad. Pariwisata Halal Perspektif Multidimensi; Peta Jalan Menuju Pengembangan Akademik \& Industri Halal Di Indonesia. Malang: UIN Maliki Press, 2017.

Fandeli, Chafid. Dasar-Dasar Manajemen Kepariwisataan, n.d.

Handoko, T. Hani. Manajemen. Yogyakarta, 2004.

Hasan, Alwi, and Dkk. Kamus Besar Bahasa Indonesia. Jakarta: Departemen Pendidikan Nasional Balai Pustaka, 2005.

Hasibuan, Melayu S. P. Organisasi Dan Motivasi. Jakarta: PT. Bumi Aksara, 2001.

Keating, Charles J. Kepemimpinan Teori Dan Pengembangannya. Yogyakarta: Kanisius, 1995. 
Ahyak

Kuncoro, Mudrajad. Strategi Bagaimana Meraih Keuggulan Kompetitif. Jakarta: Erlangga, 2006.

Manulang, M. Dasar-Dasar Managemen. Jakarta: Ghalia Indonesia, 1982.

Pitana, I Gede, and Putu G. Gayatri. Sosiologi Pariwisata. Yogyakarta: ANDI, 2007.

Purwanto, Iwan. Manajemen Strategi. Bandung: Yarma Widya, 2006.

Rosyad Shaleh, Abdullah. Manajemen Dakwah Islam. Jakarta: PT. Bulan Bintang, 1986.

S, N, Arifin, and Ruslan. Ziarah Wali Spritual Spanjang Masa, n.d.

Salusu, J. Pengambilan Keputusan Strategi Untuk Organisasi Publik Dan Organisasi Non Profit. Jakarta: PT. Grasindo, 2003.

Smith, J. Prinsip-Prinsip Manajemen. Jakarta: PT. Bumi Aksara, 1993.

Suryono, Agus. Paket Wisata Ziarah Umat Islam. Semarang: Kerjasama Dinas Pariwisata Jawa Tengah dan Stiepari Semarang, 2004.

Syukai. "Manfaat Dan Proses Manajemen Strategi." http://syukai.wordpress.com/2009/06/15/manfaat-danproses-manajemenstrategi/.

Tjiptowardoyo, Sularno. Strategi Manajemen. Jakarta: PT. Elex Media Komputindo, 1995.

Widagdyo, Kurniawan Gilang. "Analisis Pasar Pariwisata Halal Indonesia." The Journal of Tauhidinomics Vol.1 No.1 (2015): 73-80.

Yoeti, Oka, A. Pemasaran Pariwisata. Bandung: Angkasa, 1996.

Zeid Muhammad Yusuf (Takmir MASA Bidang Peribadatan), "Wawancara", Surabaya 30 Mei 2018

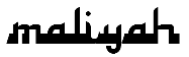

